\title{
Akurasi dan Presisi Metode Sekunder Pengukuran Konduktivitas Menggunakan Sel Jones Tipe E untuk Pemantauan Kualitas Air Minum
}

\author{
Ayu Hindayani ${ }^{\text {a, }}$, Nuryatini Hamim ${ }^{\text {a }}$ \\ ${ }^{a}$ Pusat Riset dan Pengembangan Sumber Daya Manusia - Badan Standardisasi Nasional (PUSRISBANG SDM - BSN) Gedung 430 Kawasan PUSPIPTEK, \\ Serpong, Tangerang Selatan - Banten 15314 \\ * corresponding author : ayuhindayani@gmail.com \\ DOI : $10.20885 /$ ijca.vol5 iss 1 .art5
}

\begin{tabular}{|c|c|}
\hline ARTIKEL INFO & ABSTRAK \\
\hline $\begin{array}{ll}\text { Diterima } & : 04 \text { November } 2021 \\
\text { Direvisi }: 16 \text { Januari } 2022 \\
\text { Diterbitkan }: 01 \text { Maret } 2022 \\
\text { Kata kunci : Akurasi, Kualitas air } \\
\text { minum, Presisi, Sel Jones Tipe E }\end{array}$ & $\begin{array}{l}\text { Konduktivitas merupakan indikator adanya polutan dalam air } \\
\text { minum yang dapat digunakan dalam pemantauan kualitas air } \\
\text { minum. Nilai konduktivitas yang tinggi dalam air minum } \\
\text { menunjukkan adanya logam terlarut yang berbahaya bagi } \\
\text { kesehatan. Hasil pengukuran konduktivitas yang salah akan } \\
\text { mempengaruhi pengambilan keputusan yang berdampak langsung } \\
\text { pada kesehatan manusia. Hasil pengukuran konduktivitas yang } \\
\text { akurat dan presisi dapat diperoleh dengan mengkalibrasi } \\
\text { konduktometer menggunakan larutan standar konduktivitas yang } \\
\text { tertelusur. Penelitian dan pengembangan terkait pembuatan larutan } \\
\text { standar konduktivitas di Indonesia untuk pemantauan kualitas air } \\
\text { minum telah dimulai oleh laboratorium Elektrokimia SNSU - BSN } \\
\text { sebagai lembaga metrologi nasional. Metode yang digunakan } \\
\text { adalah metode sekunder menggunakan sel Jones tipe E yang } \\
\text { tertelusur ke Sistem Satuan Internasional melalui larutan standar } \\
\text { primer CRM1811 dari DFM, Denmark. Sel Jones tipe E adalah } \\
\text { tabung gelas yang berisi dua buah elektroda platina lingkaran } \\
\text { dengan diameter } 20 \text { mm, jarak antara kedua elektroda } 20 \text { mm, dan } \\
\text { dapat digunakan pada rentang pengukuran konduktivitas } 100 \\
\mu \text { S/cm - } 1 \text { mS/cm. Akurasi dan presisi metode ini telah diperiksa } \\
\text { menggunakan larutan standar sekunder ZMK-CRM-EC-147 } \\
\text { sebelum digunakan dalam pengukuran nilai konduktivitas larutan } \\
\text { standar yang akan dibuat. Hasil penelitian menunjukkan bahwa } \\
\text { metode pengukuran konduktivitas sekunder menggunakan sel } \\
\text { Jones tipe E memiliki akurasi dan presisi yang baik dengan nilai } \\
\text { bias } 0,1 \text { S/cm dan RSD 0,04\%. }\end{array}$ \\
\hline
\end{tabular}

\begin{tabular}{l} 
ARTICLE INFO \\
\hline Received : 04 November 2021 \\
Revised : 16 January 2022 \\
Published : 01 March 2022 \\
Keywords : Accuracy, Quality of \\
drinking water, Precision, Jones Cell \\
Type E
\end{tabular}

ARTICLE INFO

Revised : 16 January 2022

Published : 01 March 2022

Keywords : Accuracy, Quality of

Type E

\begin{abstract}
Konduktivitas merupakan indikator adanya polutan dalam air minum yang dapat digunakan dalam pemantauan kualitas air minum. Nilai konduktivitas yang tinggi dalam air minum menunjukkan adanya logam terlarut yang berbahaya bagi kesehatan. Hasil pengukuran konduktivitas yang salah akan pada kesehatan manusia. Hasil pengukuran konduktivitas yang akurat dan presisi dapat diperoleh dengan mengkalibrasi konduktometer menggunakan larutan standar konduktivitas yang standar konduktivitas di Indonesia untuk pemantauan kualitas air minum telah dimulai oleh laboratorium Elektrokimia SNSU - BSN sebagai lembaga metrologi nasional. Metode yang digunakan adalah metode sekunder menggunakan sel Jones tipe E yang primer CRM1811 dari DFM, Denmark. Sel Jones tipe E adalah tabung gelas yang berisi dua buah elektroda platina lingkaran dengan diameter $20 \mathrm{~mm}$, jarak antara kedua elektroda $20 \mathrm{~mm}$, dan $\mu \mathrm{S} / \mathrm{cm}-1 \mathrm{mS} / \mathrm{cm}$. Akurasi dan presisi metode ini telah diperiksa menggunakan larutan standar sekunder ZMK-CRM-EC-147 sebelum digunakan dalam pengukuran nilai konduktivitas larutan standar yang akan dibuat. Hasil penelitian menunjukkan bahwa Jones tipe E memiliki akurasi dan presisi yang baik dengan nilai bias $0,1 \mathrm{~S} / \mathrm{cm}$ dan RSD 0,04\%.
\end{abstract}

ABSTRAK 
Accurate and precise of conductivity measurement results can be obtained by calibrating the conductivity meter using a traceable conductivity standard solution. Research and development related to the production of conductivity standard solutions in Indonesia for monitoring the quality of drinking water has been initiated by laboratory of Electrochemistry, SNSU - BSN as a national metrology institution. The method used is a secondary method using Jones cell type E which traceable to the International System of Units through the primary standard solution CRM1811 from DFM, Denmark. Jones cell type $E$ is a glass tube containing two platinum electrode circles with a diameter of $20 \mathrm{~mm}$, the distance between the two electrodes of $20 \mathrm{~mm}$, and can be used in the range of conductivity measurement of $100 \mu \mathrm{S} / \mathrm{cm}-1 \mathrm{mS} / \mathrm{cm}$. The accuracy and precision of this method have been checked using the secondary standard solution ZMK-CRM-EC-147 before used in the measurement of conductivity value for standard solution to be made. The results showed that the secondary conductivity measurement method using Jones cell type E has good accuracy and precision with a bias value of $0.1 \mathrm{~S} / \mathrm{cm}$ and an RSD of $0.04 \%$.

\section{PENDAHULUAN}

Air minum merupakan salah satu kebutuhan utama bagi manusia selain makanan. Hal ini dikarenakan sebagian besar tubuh manusia, yaitu sekitar $70-80 \%$ terdiri dari air yang tersebar dalam sel, jaringan, dan organ $[1,2,3]$. Air dalam tubuh manusia digunakan sebagai zat pembangun, pembawa nutrisi, pengatur suhu tubuh, dan zat pelarut. Kebutuhan air rata-rata orang dewasa yaitu 2 liter air atau 8 gelas berukuran $230 \mathrm{ml}$ per hari $[4,5,6]$. Kekurangan air minum dalam tubuh dapat menyebabkan gejala dehidrasi yang berakibat pada gangguan fisiologis dan respon kerja tubuh. Sedangkan kelebihan air minum dalam tubuh dapat menyebabkan hiponatremia yaitu rendahnya kadar natrium dalam darah yang berpotensi mengancam jiwa [4]. Selain dibutuhkan dalam jumlah yang cukup, air minum yang dikonsumsi harus dipastikan berasal dari sumber yang bersih dan aman dikonsumsi agar tidak membahayakan kesehatan.

Air minum yang dikonsumsi masyarakat Indonesia berasal dari sumber yang beragam, antara lain: air tanah $(11,61 \%)$, air sumur $(49,92 \%)$, mata air $(13,92 \%)$, air sungai $(4,91 \%)$, air hujan (2,62\%), dan Perusahaan Daerah Air Minum atau PDAM (16,08\%) [7]. Namun, tidak semua wilayah di Indonesia mendapatkan sumber air minum yang bersih dan aman dikonsumsi. Masih terdapat $15 \%$ masyarakat Indonesia yang belum mendapatkan sumber air minum yang bersih dan aman dikonsumsi. Hal ini dikarenakan terdapat kelangkaan sumber air baku akibat berkurangnya lahan terbuka hijau serta buruknya kualitas sumber air minum akibat pencemaran air oleh limbah industri maupun limbah rumah tangga yang mengakibatkan $82 \%$ sungai di Indonesia tercemar [8, 9]. Mengkonsumsi air minum dari sumber yang tercemar sangat membahayakan kesehatan, karena dapat menyebabkan berbagai penyakit seperti diare, tifus, dan kolera. WHO mencatat 500 ribu orang meninggal per tahun di dunia akibat diare karena mengkonsumsi air minum yang tercemar. Diare juga menjadi penyebab kematian nomor 2 pada balita dan nomor 3 pada bayi di Indonesia. Sedangkan tifus menyebabkan kematian 117 ribu orang per tahun dan kolera menyebabkan 95 ribu kematian per tahun di seluruh dunia $[10,11,12]$.

Air minum yang bersih dan aman dikonsumsi yaitu air yang tidak mengandung mikroorganisme, zat kimia dan zat berbahaya lainnya yang mengancam kesehatan apabila dikonsumsi. Beberapa parameter yang digunakan untuk menilai kualitas air minum yang bersih dan aman dikonsumsi, antara lain: warna, rasa, bau, mikrobiologi, $\mathrm{pH}$, dan konduktivitas $[13,14,15]$. Konduktivitas merupakan salah satu parameter penting dalam menilai kualitas air minum, karena dapat dijadikan indikator keberadaan polutan dalam air minum dengan memprediksi banyaknya mineral yang terlarut [16]. Kandungan mineral terlarut dalam air minum seperti flourida, natrium, magnesium, kalsium, selenium, tembaga, dan seng sangat bermanfaat bagi tubuh, diantaranya dapat meningkatkan kesehatan tulang, menurunkan tekanan darah, menjaga keseimbangan elektrolit, dan 
menjaga sistem pencernaan. Namun kandungan mineral dalam air minum tidak boleh melebihi kadar maksimum yang diperbolehkan dalam Peraturan Menteri Kesehatan No. 492/Menkes/Per/VI/2010 [17]. Kadar mineral yang tinggi pada air minum menyebabkan kesadahan pada air yang apabila dikonsumsi dapat menyumbat pembuluh darah jantung dan batu ginjal [18, 19]. Semakin banyak mineral terlarut dalam air, maka nilai konduktivitasnya akan semakin tinggi. Standar konduktivitas untuk air minum yang diperbolehkan WHO yaitu tidak melebihi $400 \mu \mathrm{S} / \mathrm{cm}$ [20].

Kandungan mineral dalam air minum dapat diketahui dengan mengukur konduktivitasnya menggunakan konduktometer. Untuk mendapatkan hasil pengukuran yang akurat, konduktometer harus dikalibrasi dengan larutan standar konduktivitas yang tertelusur ke sistem satuan internasional (SI). Hasil pengukuran konduktivitas yang akurat akan membantu pihak berwenang dalam proses pengambilan keputusan atau kebijakan terkait kualitas air minum yang akan berdampak langsung pada kesehatan manusia serta lingkungan. Selain mendapatkan hasil pengukuran yang akurat, mengkalibrasi konduktometer secara rutin dengan larutan standar konduktivitas yang tertelusur dapat menjamin hasil pembacaan yang presisi, dapat diandalkan, dan mendapatkan hasil pengukuran yang tertelusur ke SI seperti yang dipersyaratkan dalam klausul 6.5 pada ISO/IEC 17025:2017 [21, 22]. Larutan standar konduktivitas yang biasa digunakan untuk kalibrasi konduktometer adalah larutan kalium klorida $(\mathrm{KCl})$ karena sifatnya yang mudah larut dan stabil [23]. Sayangnya, ketersediaan larutan standar konduktivitas yang tertelusur di Indonesia masih sulit didapatkan, karena masih bergantung pada pasokan impor dari luar negeri. Sehingga membutuhkan waktu yang lama dan biaya yang tidak sedikit. Maka dari itu pengembangan larutan standar konduktivitas di dalam negeri sangat penting dilakukan untuk memenuhi kebutuhan laboratorium pengujian yang ada di Indonesia serta menjaga hasil pengukuran konduktivitas di Indonesia tertelusur ke SI.

Penelitian dan pengembangan terkait pembuatan larutan standar konduktivitas untuk kalibrasi konduktometer dalam pemantauan kualitas air minum telah mulai dilakukan oleh Laboratorium Elektrokimia, Standar Nasional Satuan Ukuran - Badan Standardisasi Nasional (SNSU - BSN) sebagai bagian dari lembaga metrologi nasional. Larutan standar konduktivitas yang akan dibuat diukur nilai konduktivitasnya dengan metode sekunder menggunakan Sel Jones Tipe E. Metode sekunder yaitu pengukuran konduktivitas dimana konstanta sel nya diukur menggunakan larutan standar primer yang tertelusur ke SI. Larutan standar primer yang digunakan ini diukur nilai konduktivitasnya dengan metode primer, dimana konstanta sel nya diperoleh melalui pengukuran dimensi fisik geometri sel yang tertelusur langsung ke SI. Sehingga metode sekunder dikatakan tertelusur ke SI melalui larutan standar primer. Kemudian, larutan standar yang diukur nilainya dengan metode sekunder disebut larutan standar sekunder. Larutan standar sekunder ini selanjutnya dapat digunakan untuk mengkalibrasi konduktometer yang digunakan untuk mengukur sampel dalam pemantauan kualitas air minum. Hasil pengukuran dengan konduktometer ini dikatakan tertelur ke SI melalui larutan standar sekunder [24, 25]. Piramida ketertelusuran pengukuran konduktivitas terdapat dalam Gambar 1. 


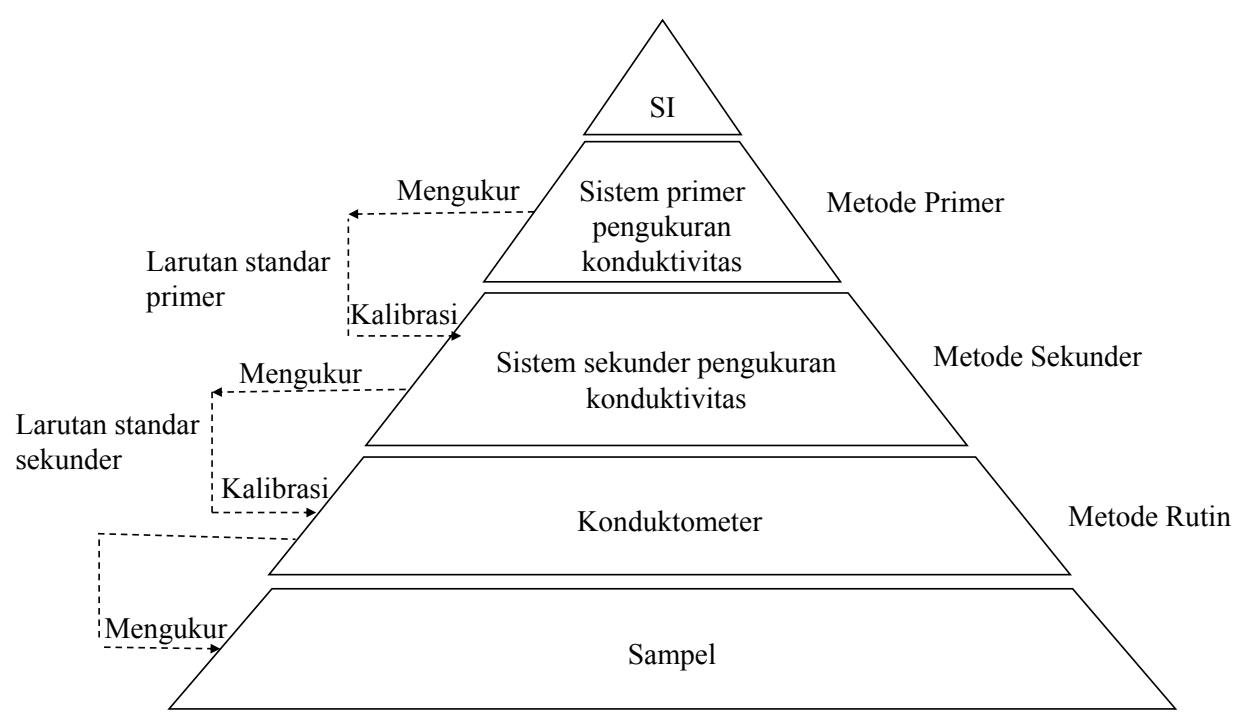

Gambar 1. Piramida ketertelusuran pengukuran konduktivitas

Laboratorium Elektrokimia, SNSU - BSN menggunakan metode sekunder pengukuran konduktivitas dengan Sel Jones tipe E untuk mengukur nilai konduktivitas larutan standar sekunder yang akan dibuat untuk kalibrasi konduktometer yang digunakan untuk mengukur sampel dalam pemantauan kualitas air minum. Metode ini merupakan metode tertinggi pengukuran konduktivitas yang dimiliki Indonesia. Namun sebelum metode ini digunakan, akurasi dan presisi dari metode tersebut harus ditentukan terlebih dahulu untuk menjamin hasil pengukuran yang valid, akurat, dan handal $[26,27,28]$. Penentuan akurasi dan presisi metode sekunder pengukuran konduktivitas dengan Sel Jones tipe E dibahas secara detail dalam makalah ini.

\section{METODE}

Larutan standar primer CRM1811 $\left(100,06 \mu \mathrm{S} / \mathrm{cm}\right.$ pada $\left.25^{\circ} \mathrm{C}\right)$ dipesan dari DFM (Danish Fundamental Metrology atau Lembaga Metrologi Nasional Denmark) digunakan dalam pemilihan frekuensi pengukuran dan penentuan konstanta Sel Jones tipe E. Larutan standar sekunder ZMKCRM-EC-147 $\left(147,5 \mu \mathrm{S} / \mathrm{cm}\right.$ dengan ketidakpastian standar $0,1 \mu \mathrm{S} / \mathrm{cm}$ pada $\left.25^{\circ} \mathrm{C}\right)$ dipesan dari ZMK\&ANALYTIK GmbH, Jerman digunakan dalam penentuan akurasi dan presisi metode pengukuran. Satu set sistem sekunder pengukuran konduktivitas (Gambar 2) terdiri dari Sel Jones tipe E, penangas air (Proline PV36, Lauda Jerman), pendingin (DLK25, Lauda Jerman), alat pengukur suhu (MKT50, Anton Paar Jerman dilengkapi dengan sensor Pt100) dan LCR meter (8105G, GW-Instek Taiwan) digunakan dalam pengukuran.

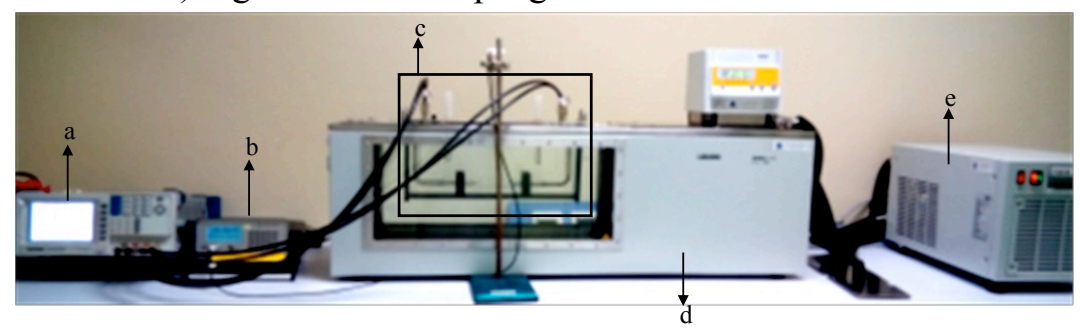

Gambar 2. Satu set sistem sekunder pengukuran konduktivitas: a) LCR meter, b) alat pengukur suhu, c) Sel Jones Tipe E, d) penangas air, e) pendingin [29]

\subsection{Penentuan Akurasi Metode}

Akurasi suatu metode yaitu ukuran kedekatan suatu hasil pengukuran dengan nilai yang sebenarnya. Penentuan akurasi sangat penting dilakukan untuk meningkatkan kepercayaan atas hasil pengukuran dan mengetahui kinerja dari suatu metode. Akurasi suatu metode dievaluasi menggunakan bias, yaitu perbedaan rata-rata hasil pengukuran $(\overline{\mathrm{X}})$ dengan nilai acuan pada sertifikat larutan standar ( $\left.\mathrm{X}_{\text {larutan standar }}\right)$ yang terdapat dalam persamaan (1) [30, 31]. 
$\mathrm{b}=\left|\overline{\mathrm{X}}-\mathrm{X}_{\text {larutan standar }}\right|$

Pada penentuan akurasi metode, larutan standar sekunder ZMK-CRM-EC-147 diukur resistansinya (R) sebanyak 10 kali pada frekuensi pengukuran yang paling linear. Kemudian hasil pengukuran dikonversi menjadi konduktivitas $(\kappa)$. Suatu metode dikatakan akurat apabila nilai bias yang didapatkan memenuhi kriteria $-2 \sigma<\mathrm{b}<2 \sigma$, dimana nilai $\sigma$ dihitung menggunakan persamaan (2) [32].

$\sigma=\sqrt{u_{\text {bahan acuan }}^{2}+\frac{s_{w}^{2}}{n}}$

Dengan $\mathrm{u}_{\text {bahan acuan }}$ adalah ketidakpastian standar ZMK-CRM-EC-147, $\mathrm{s}_{\mathrm{w}}$ adalah standar deviasi pengukuran bahan acuan, dan $\mathrm{n}$ adalah banyaknya pengukuran, dimana pada penelitian ini dilakukan pengukuran sebanyak 10 kali.

\subsection{Penentuan Presisi Metode}

Presisi suatu metode yaitu ukuran kedekatan antara hasil pengukuran yang satu dengan hasil pengukuran yang lainnya di bawah kondisi yang sama atau pengulangan (repeatability). Presisi ini dinyatakan sebagai persen simpangan baku relatif (\%RSD) yang dihitung menggunakan persamaan (3). Pada penelitian ini, presisi metode ditentukan dengan mengukur $\mathrm{R}$ larutan standar sekunder ZMK-CRM-EC-147 sebanyak 10 kali pada kondisi yang sama (alat, waktu dan analis).

$\% \mathrm{RSD}=\frac{\text { standar deviasi }}{\overline{\mathrm{x}}} \times 100$

Suatu metode dikatakan presisi apabila memenuhi kriteria $\%$ RSD $\leq \%$ RSD Horwitz. Nilai dari \% RSD Horwitz dihitung menggunakan persamaan (4) [33].

$\% \mathrm{RSD}_{\text {Horwitz }}=\mathrm{C}^{-0,15}$

Dimana C merupakan konsentrasi larutan standar sekunder ZMK-CRM-EC-147, yaitu KCl 0,001 $M$ yang nilainya setara dengan $0,00745 \%$.

\subsection{Pemilihan Frekuensi Pengukuran}

Pada metode sekunder pengukuran konduktivitas, terdapat hubungan linear antara $\mathrm{R}$ dengan 1/f pada rentang frekuensi tertentu yang tidak didapatkan pada semua rentang frekuensi pengukuran. Pemilihan frekuensi yang sesuai akan menghasilkan pengukuran konduktivitas yang tepat [25]. Pada penelitian ini, penentuan frekuensi ditentukan dengan mengukur $\mathrm{R}$ larutan standar primer CRM1811 pada frekuensi $20-5000 \mathrm{~Hz}, 20-500 \mathrm{~Hz}$, dan $35-100 \mathrm{~Hz}$ menggunakan LCR meter. Pada masing-masing frekuensi, dilakukan pengukuran sebanyak 10 kali dan rata-rata hasil pengukuran dibuat kurva regresi linear antara $R$ terhadap $1 / f$ dan dicari koefisien regresi linear $\left(R^{2}\right)$ nya. Rentang frekuensi yang sesuai dalam pengukuran adalah yang paling linear dengan nilai $\mathrm{R}^{2}>$ 0,999 [34]. Hal ini menunjukkan pengukuran telah dilakukan pada rentang frekuensi yang sesuai [25]. Selanjutnya rentang frekuensi yang sesuai digunakan dalam penentuan konstanta Sel Jones tipe E serta pengukuran nilai konduktivitas larutan standar sekunder ZMK-CRM-EC-147.

\subsection{Penentuan Konstanta Sel}

Konstanta sel $\left(\mathrm{K}_{\text {sel }}\right)$ adalah faktor yang digunakan untuk mengkonversi konduktansi $(\mathrm{G})$ menjadi konduktivitas $(\kappa)$ yang digambarkan dalam persamaan (5). Nilai $\mathrm{K}_{\text {sel }}$ metode sekunder dapat diukur dengan menggunakan larutan standar primer yang diketahui nilai konduktivitasnya dan tertelusur $[24,25]$. Pada penelitian ini, Laboratorium Elektrokimia, SNSU - BSN menggunakan larutan standar primer CRM1811 dari DFM, Denmark sehingga metode sekunder dengan Sel Jones tipe E dikatakan tertelusur ke SI melalui CRM1811 dari DFM. 
$\kappa=\mathrm{K}_{\mathrm{sel}} \times \mathrm{G}$

Penentuan $\mathrm{K}_{\text {sel }}$ diawali dengan memasukkan larutan standar primer CRM1811 ke dalam Sel Jones tipe $\mathrm{E}$ dan dipastikan tidak terdapat gelembung yang menempel pada elektroda di dalam sel, karena hal ini dapat mengurangi luas permukaan efektif elektroda, meningkatkan nilai resistansi, dan menurunkan nilai konduktivitas sampel [35]. Sel Jones tipe E yang sudah diisi kemudian dimasukkan ke dalam penangas air untuk menjaga suhu pengukuran stabil pada $25^{\circ} \mathrm{C}$. Selanjutnya sel dihubungkan dengan LCR meter dan diukur R nya pada rentang frekuensi yang paling linear. pengukuran R larutan standar primer CRM1811 dilakukan sebanyak 10 kali. Kurva regresi linear antara $\mathrm{R}$ terhadap $1 / \mathrm{f}$ dibuat untuk mendapatkan persamaan garis $\mathrm{y}=\mathrm{mx}+\mathrm{c}$, dimana $\mathrm{m}$ adalah tingkat kemiringan garis dan c adalah intersep yaitu nilai rata-rata hasil pengukuran $\mathrm{R}$ (dalam satuan Ohm, $\Omega$ ) yang akan digunakan untuk menghitung nilai $\mathrm{G}$ (dalam satuan Siemens, S) seperti pada persamaan (6). Kemudian $\mathrm{K}_{\text {sel }}$ dihitung menggunakan persamaan (7).

$\mathrm{G}=\frac{1}{\mathrm{R}}$

$\mathrm{K}_{\mathrm{sel}}=\frac{\mathrm{\kappa}}{\mathrm{G}}$

dimana $\kappa$ adalah nilai konduktivitas larutan standar primer CRM1811 berdasarkan sertifikat, yaitu $100,06 \mu \mathrm{S} / \mathrm{cm}$ pada $25^{\circ} \mathrm{C}$.

\subsection{Pengukuran konduktivitas}

Larutan standar sekunder ZMK-CRM-EC-147 dimasukkan ke dalam Sel Jones tipe E dan dipastikan tidak terdapat gelembung di dalam sel. Kemudian, sel dimasukkan ke dalam penangas air untuk menjaga suhu pengukuran stabil pada $25^{\circ} \mathrm{C}$. Selanjutnya sel dihubungkan dengan LCR meter dan diukur $\mathrm{R}$ nya pada rentang frekuensi yang paling linear. Pengukuran ini dilakukan sebanyak 10 kali. Kurva regresi linear antara $\mathrm{R}$ terhadap 1/f dibuat untuk mendapatkan persamaan garis $\mathrm{y}=\mathrm{mx}+\mathrm{c}$, dimana $\mathrm{m}$ adalah tingkat kemiringan garis dan $\mathrm{c}$ adalah intersep yaitu nilai ratarata hasil pengukuran $\mathrm{R}$ yang akan digunakan untuk menghitung nilai $\mathrm{G}$ seperti pada persamaan (6). Nilai konduktivitas ( $\kappa$ ) larutan standar sekunder ZMK-CRM-EC-147 dihitung sesuai persamaan (5) dengan nilai $\mathrm{K}_{\text {sel }}$ yang telah didapatkan sebelumnya.

\section{HASIL PENELITIAN}

Konduktivitas merupakan salah satu parameter yang dapat dijadikan indikator kualitas air minum yang aman dikonsumsi. Pengukuran yang tepat dan akurat dapat diperoleh dengan mengkalibrasi konduktometer dengan larutan standar konduktivitas yang tertelusur. Sebagai bagian dari lembaga metrologi nasional, Laboratorium Elektrokimia, SNSU - BSN telah mulai melakukan penelitian dan pengembangan terkait pembuatan larutan standar konduktivitas yang tertelusur dengan metode sekunder menggunakan Sel Jones tipe E. Sel ini merupakan tabung gelas dengan dua elektroda platina $(\mathrm{Pt})$ lingkaran berdiameter $20 \mathrm{~mm}$ dengan jarak antara elektroda yaitu $20 \mathrm{~mm}$ dan dapat digunakan pada rentang pengukuran konduktivitas $100 \mu \mathrm{S} / \mathrm{cm}-1 \mathrm{mS} / \mathrm{cm}$ [25]. Sehingga sesuai digunakan untuk pengukuran larutan standar konduktivitas $\mathrm{KCl}$ 0,001 $\mathrm{M}$ yang akan dibuat sebagai larutan pengkalibrasi konduktometer yang digunakan untuk mengukur sampel dalam pemantauan kualitas air minum. Larutan ini memiliki nilai konduktivitas sekitar $147 \mu \mathrm{S} / \mathrm{cm}$ pada $25^{\circ} \mathrm{C}$. Selain akan mengembangkan larutan standar konduktivitas $\mathrm{KCl} 0,001 \mathrm{M}$ untuk aplikasi pemantauan air minum, Laboratorium Elektrokimia, SNSU - BSN telah melakukan pengembangan larutan standar konduktivitas sebagai larutan kalibrasi konduktometer yang digunakan untuk mengukur sampel dalam pemantauan air limbah, yaitu $\mathrm{KCl} 0,1 \mathrm{M}\left(12,880 \mathrm{mS} / \mathrm{cm}\right.$ pada $\left.25^{\circ} \mathrm{C}\right)$ menggunakan Sel Jones tipe $\mathrm{C}$ dan larutan standar konduktivitas sebagai larutan kalibrasi 
konduktometer yang digunakan untuk mengukur sampel dalam pemantauan kualitas air laut, yaitu $\mathrm{KCl} 1 \mathrm{M}\left(111,6 \mathrm{mS} / \mathrm{cm}\right.$ pada $\left.25^{\circ} \mathrm{C}\right)$ menggunakan Sel Jones tipe D [29, 36]. Larutan $\mathrm{KCl} 0,1 \mathrm{M}$ juga telah didiseminasikan kepada laboratorium pengujian di Indonesia melalui uji profisiensi pada tahun 2017 [37]. Keberadaan larutan standar konduktivitas yang tertelusur ini diharapkan dapat membantu mencukupi kebutuhan laboratorium pengujian yang ada di Indonesia untuk mengkalibrasi konduktometer serta menjaga ketertelusuran hasil pengukuran konduktivitas ke SI.

Sebagai bagian dari lembaga metrologi nasional, Laboratorium Elektrokimia, SNSU - BSN memiliki sistem sekunder pengukuran konduktivitas dengan Sel Jones sebagai ketertelusuran tertinggi yang dimiliki Indonesia. Sel Jones yang dimiliki antara lain: Sel Jones tipe A untuk rentang pengukuran konduktivitas $2-15 \mu \mathrm{S} / \mathrm{cm}$, Sel Jones tipe B untuk rentang pengukuran konduktivitas $15-100 \mu \mathrm{S} / \mathrm{cm}$, Sel Jones tipe $\mathrm{C}$ untuk rentang pengukuran konduktivitas $1-20$ $\mathrm{mS} / \mathrm{cm}$, Sel Jones tipe D untuk rentang pengukuran konduktivitas $20-100 \mathrm{mS} / \mathrm{cm}$, dan Sel Jones tipe E untuk rentang pengukuran konduktivitas $100 \mu \mathrm{S} / \mathrm{cm}-1 \mathrm{mS} / \mathrm{cm}$ [25]. Sebelum digunakan dalam pengukuran, setiap Sel Jones harus diperiksa akurasi dan presisinya.

Sel Jones tipe E yang akan digunakan dalam pengukuran larutan standar konduktivitas $\mathrm{KCl}$ 0,001 M yang akan dibuat, ditentukan terlebih dahulu rentang frekuensi yang sesuai dalam pengukuran. Karena hasil pengukuran konduktivitas yang tepat akan dihasilkan dari pemilihan rentang frekuensi yang sesuai. Biasanya frekuensi rendah digunakan untuk larutan yang memiliki nilai konduktivitas kecil, sedangkan frekuensi tinggi digunakan untuk larutan yang memiliki nilai konduktivitas tinggi [25]. Pada penelitian ini dilakukan pengukuran konduktivitas standar primer CRM1811 pada rentang frekuensi $20-5000 \mathrm{~Hz}, 20-500 \mathrm{~Hz}$, dan $35-100 \mathrm{~Hz}$ yang dilakukan sebanyak 10 kali pada masing-masing rentang frekuensi. Hasil penelitian pada Gambar 3 menunjukkan pengukuran CRM1811 pada rentang frekuensi $35-100 \mathrm{~Hz}$ merupakan kurva yang paling linear dengan nilai $\mathrm{R}^{2}$ sebesar 0,9998 . Hal ini menunjukkan $35-100 \mathrm{~Hz}$ merupakan rentang frekuensi paling sesuai digunakan dalam pengukuran konduktivitas CRM1811 yang memiliki nilai $100,06 \mu \mathrm{S} / \mathrm{cm}$ [25]. Selanjutnya rentang frekuensi ini digunakan untuk penentuan konstanta Sel Jones tipe E dan pengukuran konduktivitas larutan standar sekunder ZMK-CRM-EC-147.

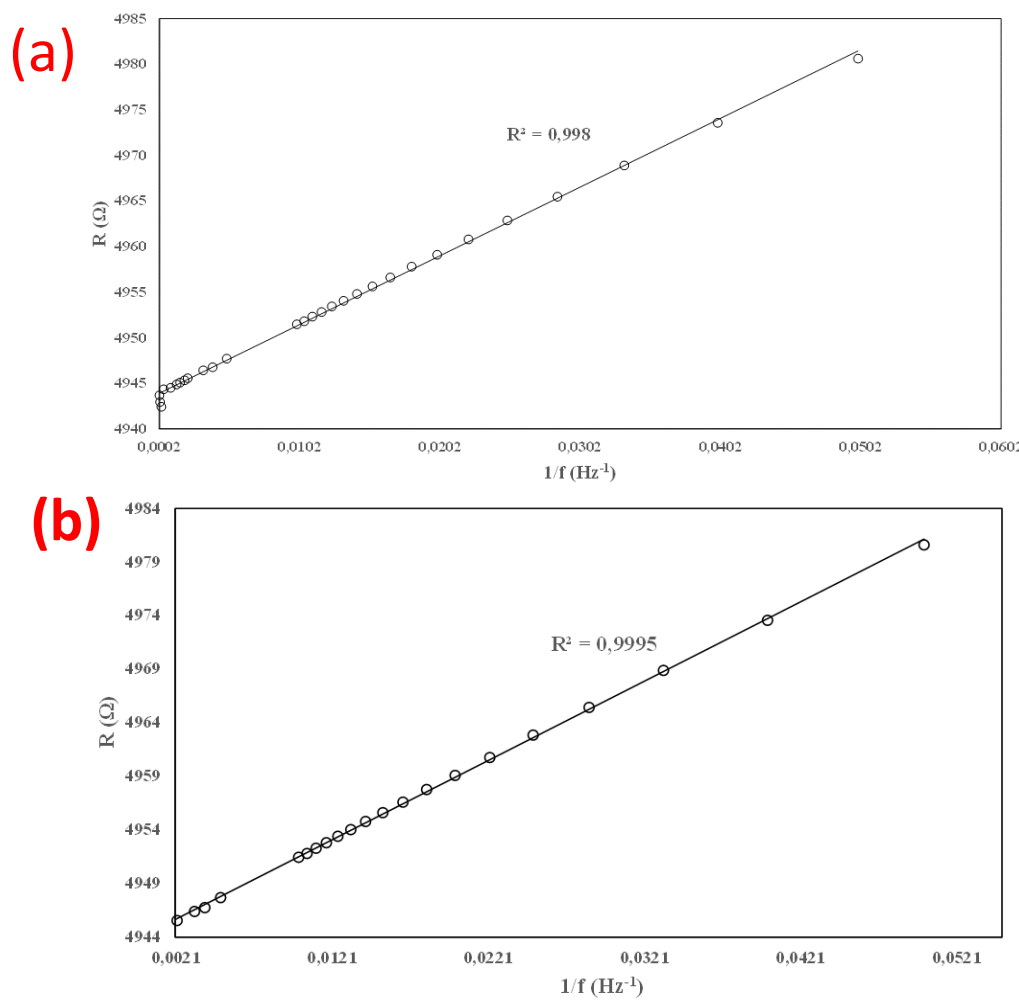




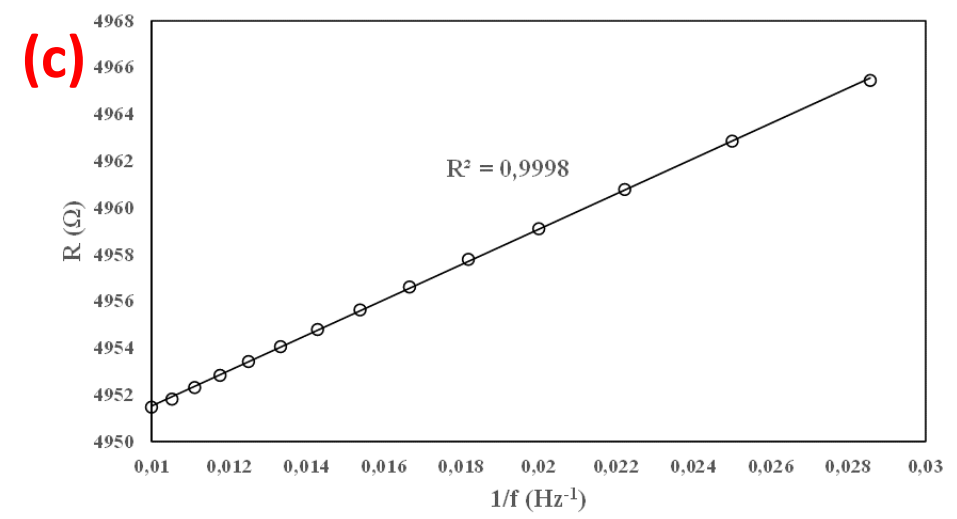

Gambar 3. Pengukuran R larutan standar primer CRM1811 pada rentang frekuensi:

a) $20-5000 \mathrm{~Hz}$, b) $20-500 \mathrm{~Hz}$, c) $35-100 \mathrm{~Hz}$

Selanjutnya konstanta Sel Jones tipe E ditentukan untuk menghitung nilai konduktivitas larutan standar sekunder ZMK-CRM-EC-147 karena konduktivitas tidak dapat diukur secara langsung [38]. Selain itu, setiap sel konduktivitas memiliki konstanta sel yang perlu ditentukan secara teratur, karena nilai konstanta sel dapat berubah seiring berjalannya waktu [39]. Pada penelitian ini digunakan larutan standar primer CRM1811 dari DFM untuk penentuan konstanta sel. Sehingga metode sekunder pengukuran konduktivitas dengan Sel Jones tipe E dikatakan tertelusur ke DFM. Hasil pengukuran pada Tabel 1 menunjukkan Sel Jones tipe E memiliki konstanta sel sebesar $0,495 \mathrm{~cm}^{-1}$.

TABEL I. Hasil Pengukuran Konstanta Sel Jones Tipe E

\begin{tabular}{lllll}
\hline Pengukuran ke- & $\mathrm{R}(\Omega)$ & $\mathrm{G}(\mu \mathrm{S})$ & $\kappa \mathrm{CRM} 1811(\mu \mathrm{S} / \mathrm{cm})$ & $\mathrm{K}_{\text {sel }}\left(\mathrm{cm}^{-1}\right)$ \\
\hline 1 & 4919,5 & 203,273 & & 0,492 \\
2 & 4944,1 & 202,261 & & 0,495 \\
3 & 4910,2 & 203,658 & & 0,491 \\
4 & 4938,9 & 202,474 & & 0,494 \\
5 & 4945,1 & 202,220 & 100,06 & 0,495 \\
6 & 4960,5 & 201,593 & & 0,496 \\
7 & 4960 & 201,613 & & 0,496 \\
8 & 4955,5 & 201,796 & 0,496 \\
9 & 4952,2 & 201,930 & 0,496 \\
10 & 4953,5 & 201,877 & 0,496 \\
\hline Rata-rata & & & 0,495 \\
\hline
\end{tabular}

Hasil penentuan $\mathrm{K}_{\text {sel }}$ pada Tabel 1 sesuai dengan nilai $\mathrm{K}_{\text {sel }}$ pada sertifikat Sel Jones tipe $\mathrm{E}$ dari ZMK\&ANALYTIK GmbH, yaitu $0,495 \mathrm{~cm}^{-1}$ [40]. Hal ini berarti nilai $\mathrm{K}_{\text {sel }}$ pada Sel Jones tipe $\mathrm{E}$ belum mengalami perubahan. Kemudian, nilai konstanta Sel Jones tipe E yang sudah didapatkan digunakan untuk menghitung konduktivitas larutan standar sekunder ZMK-CRM-EC-147. Hasil pengukuran pada Tabel 2 menunjukkan nilai rata-rata konduktivitas larutan sekunder ZMK-CRMEC-147 sebesar $147,4 \mu \mathrm{S} / \mathrm{cm}$. 
TABEL II. Hasil Pengukuran Konduktivitas Larutan Standar Sekunder ZMK-CRM-EC-147

\begin{tabular}{|c|c|c|c|c|}
\hline Pengukuran ke- & $\mathrm{R}(\Omega)$ & $\mathrm{G}(\mu \mathrm{S})$ & $\mathrm{K}_{\mathrm{sel}}\left(\mathrm{cm}^{-1}\right)$ & $\kappa(\mu \mathrm{S} / \mathrm{cm})$ \\
\hline 1 & 3360,5 & 297,576 & \multirow{10}{*}{0,495} & 147,3 \\
\hline 2 & 3359,7 & 297,646 & & 147,3 \\
\hline 3 & 3361,6 & 297,477 & & 147,3 \\
\hline 4 & 3360,8 & 297,548 & & 147,3 \\
\hline 5 & 3358,3 & 297,770 & & 147,4 \\
\hline 6 & 3357,3 & 297,858 & & 147,4 \\
\hline 7 & 3358,0 & 297,796 & & 147,4 \\
\hline 8 & 3358,1 & 297,787 & & 147,4 \\
\hline 9 & 3358,4 & 297,761 & & 147,4 \\
\hline 10 & 3358,0 & 297,796 & & 147,4 \\
\hline \multicolumn{4}{|l|}{ Rata-rata } & 147,4 \\
\hline \multicolumn{4}{|c|}{ Bias menggunakan persamaan (1) } & 0,1 \\
\hline \multicolumn{4}{|c|}{$\sigma$ menggunakan persamaan (2) } & 0,13 \\
\hline \multicolumn{4}{|c|}{ Kriteria akurat: $-2 \sigma<b<2 \sigma$} & $\mathrm{OK}$ \\
\hline \multicolumn{4}{|l|}{ Standar deviasi } & 0,06 \\
\hline \multicolumn{4}{|c|}{ \%RSD menggunakan persamaan (3) } & $0,04 \%$ \\
\hline \multicolumn{4}{|c|}{ \%RSD Horwitz menggunakan persamaan (4) } & $4,16 \%$ \\
\hline \multicolumn{4}{|c|}{ Kriteria presisi: \%RSD $\leq \% \mathrm{RSD}$ Horwitz } & $\mathrm{OK}$ \\
\hline
\end{tabular}

BerdasarkanTabel 2 didapatkan hasil pengukuran konduktivitas larutan standar sekunder ZMKCRM-EC-147 menggunakan metode sekunder dengan Sel Jones tipe E memenuhi kriteria dan bersifat akurat serta presisi. Selanjutnya metode ini dapat digunakan untuk mengukur nilai konduktivitas larutan standar konduktivitas $\mathrm{KCl}$ 0,001 M yang akan dikembangkan Laboratorium Elektrokimia, SNSU - BSN untuk kalibrasi konduktometer yang digunakan untuk mengukur sampel dalam pemantauan kualitas air minum. Keberadaan larutan standar konduktivitas ini diharapkan dapat memenuhi kebutuhan laboratorium pengujian di Indonesia serta menjaga hasil pengukuran konduktivitas tertelusur ke SI.

\section{KESIMPULAN}

Laboratorium Elektrokimia, SNSU - BSN telah mengembangkan metode sekunder pengukuran konduktivitas dengan Sel Jones tipe E yang bersifat akurat dan presisi pada rentang pengukuran $100 \mu \mathrm{S} / \mathrm{cm}-1 \mathrm{mS} / \mathrm{cm}$. Metode ini dapat digunakan untuk mengukur nilai konduktivitas larutan standar konduktivitas $\mathrm{KCl}$ 0,001 M yang akan dikembangkan. Untuk menambah kepercayaan terhadap hasil pengukuran yang didapatkan serta mendapat pengakuan di dunia internasional untuk pengukuran konduktivitas, sebaiknya dilakukan uji banding internasional dengan negara lain yang memiliki metode serupa. Kemudian, akan dilakukan studi mengenai homogenitas dan stabilitas larutan standar konduktivitas $\mathrm{KCl} 0,001 \mathrm{M}$ yang akan dibuat sebelum didiseminasikan kepada laboratorium-laboratorium pengujian di Indonesia.

\section{Ucapan Terima Kasih}

Penulis mengucapkan terima kasih kepada Pusat Penelitian Metrologi LIPI dan PTB Jerman yang telah mendukung penelitian ini.

\section{Daftar Pustaka}

[1] Y. Ernovitania and S. Sumarmi. "Hubungan Antara Pengeluaran Untuk Minum Dan Pola Konsumsi Air Dengan Status Hidrasi Pada Siswi SMP Unggulan Bina Insani Surabaya", The Indonesian Journal of Public Health., vol. 12, no. 2, pp. 276-285, 2017. 
[2] C. M. Ecelbarger, D. K. Chaudhary, H. Lee, and S. Tiwari. "Molecular Mechanisms of Body Water Homeostasis", Colloquium Series on Integrated Systems Physiology from Molecule to Function., vol. 8, no.4, pp. i-100, 2016.

[3] E. Jéquier and F. Constant. "Water as an Essential Nutrient: The Physiological basis of Hydration", European Journal of Clinical Nutrition., vol. 64, no.2, pp. 115-123, 2010.

[4] J. Lunn and R. Foxen. "How Much Water Do We Really Needs?", Journal compilation British Nutrition Foundation Nutrition Bulletin., vol. 33, no. 4, pp. 336-342, 2008.

[5] http://www.p2ptm.kemkes.go.id/infograpihc-p2ptm/hipertensi-penyakit-jantung-dan-pembuluhdarah/page/14/berapa-takaran-normal-air-agar-tidak-kekurangan-cairan-dalam-tubuh diakses pada 1407-2021.

[6] https://www.maine.gov/mdot/challengeme/topics/docs/2019/june/The-Health-Benefits-of-Water.pdf, diakses pada 15-07-2021.

[7] S. Yudo. "Pengelolaan Air Minum Berbasis Masyarakat Studi Kasus Pembangunan Air Minum Di Desa Nelayan II Kabupaten Sungai Liat, Propinsi Bangka-Belitung”, JAI., vol. 1, no.2, pp. 189-199, 2005.

[8] https://katadata.co.id/happyfajrian/berita/602f9824c6cc0/sri-mulyani-15-rakyat-indonesia-belummemiliki-akses-air-layak-minum, diakses pada 28-10-2021.

[9] https://nasional.republika.co.id/berita/nasional/umum/porsc1383/82-persen-sungai-di-indonesiatercemar-dan-kritis, diakses pada 15-07-2021.

[10] http://seafast.ipb.ac.id/air-tercemar-perut-meradang/, diakses pada 28-10-2021.

[11] J. N. Edokpayi, E. T. Rogawski, D. M. Kahler, C. L. Hill, C. Reynolds, E. Nyathi, J. A. Smith, J. O. Odiyo, A. Samie, P. Bessong, and R. Dillingham. "Challenges to Sustainable Safe Drinking Water: A Case Study of Water Quality and Use across Seasons in Rural Communities in Limpopo Province, South Africa”, Water., vol. 10, no.2, pp. 1-18, 2018.

[12] https://www.cdc.gov/healthywater/pdf/global/GlblWASHBrf_UPDATE_H.pdf, diakses pada 25-122021.

[13] M. O. Dinka. "Safe Drinking Water: Concepts, Benefits, Principles and Standards. Water Challenges of an Urbanizing World”., Water Challenges of an Urbanizing World, InTech., 2018.

[14] http://www.p2ptm.kemkes.go.id/infographic-p2ptm/hipertensi-penyakit-jantung-dan-pembuluhdarah/apa-saja-syarat-syarat-air-minum, diakses pada 16-07-2021.

[15] World Health Organization. "Nutrients in Drinking Water”, Geneva, Switzerland, 2005.

[16] Khairunnas and M. Gusman. "Analisis Pengaruh Parameter Konduktivitas, Resistivitas dan TDS Terhadap Salinitas Air Tanah Dangkal pada Kondisi Air Laut Pasang dan Air Laut Surut di Daerah Pesisir Pantai Kota Padang”, Jurnal Bina Tambang., vol. 3, no.4, pp. 1751-1760, 2018.

[17] E. R. Sedyaningsih. "Peraturan Menteri Kesehatan Nomor 492 tentang Persyaratan Kualitas Air Minum”, Kementrian Kesehatan RI, 2010.

[18] R. S. Dewi, M. I. Kusuma, and E. Kurniawati. "Pengaruh Lama Kontak Arang Kayu Terhadap Penurunan Kadar Kesadahan Air Sumur Gali Di Paal Merah II Kota Jambi”, Riset Informasi Kesehatan., vol. 7, no.1, pp. 46-54, 2018.

[19] F. Melinda, S. Laili, and A. Syauqi. "Uji Kualitas Air Minum Isi Ulang pada Depo Air Minum Di Sekitar Kampus UNISMA Malang”, Biosaintropis., vol. 3, no. 1, pp. 53-59, 2017.

[20] Meride, Y., Ayenew, B. "Drinking Water Quality Assessment and Its Effects On Residents Health In Wondo Genet Campus, Ethiopia”, Environmental System Research., vol. 5, no. 1, pp. 1-7, 2016.

[21] https://www.instrumentchoice.com.au/news/essential-solutions-to-keep-your-conductivity-meteraccurate-and-reliable, diakses pada 31-08-2021.

[22] ISO/IEC 17025:2017. "General Requirements for The Competence of Testing And Calibration Laboratories”, Geneva, Switzerland, 2017. 
[23] R. H. Shreiner, and K. W. Pratt. "Standard Reference Materials: Primary Standards and Standard Reference Materials for Electrolytic Conductivity”, NIST Special Publication 260 - 142, 2004.

[24] E. Orrù and F. Rolle. "Establishment of Metrological Traceability In Chemistry: An Overview Of Two INRiM Activities", $16^{\text {th }}$ Metrology International Congress of Metrology, 2013.

[25] U. Breuel, B. Werner, P. Spitzer, and H. D. Jensen. "Experiences with Novel Secondary Conductivity Sensors within the German Calibration Service (DKD)", NCSLI Measure., vol. 3, no.2, pp. 32-36, 2008.

[26] United Nations. "Guidance for the Validation of Analytical Methodology and Calibration of Equipment used for Testing of Illicit Drugs in Seized Materials and Biological Specimens", United Nations Publication, New York, 2009.

[27] https://www.rsc.org/images/Warwick2_tcm18-93083.pdf, diakses pada 7/8/2021.

[28] https://www.qse-academy.com/extent-purpose-and-relevance-of-iso-17025-method-validation/, diakses $7 / 8 / 2021$.

[29] A. Hindayani, O. Zuas, C. Elishian, Y. Aristiawan, and N. Hamim. "Uncertainty Estimation for The Measurement of Electrolytic Conductivity by Secondary Method Using Cell Type D", Periódico Tchê Química., vol. 16, no. 33, pp. 911-919, 2019.

[30] V. Ravichandran, S. Shalini, K. M. Sundram, and R. Harish. "Validation of Analytical Methods Strategies \& Importance", International Journal of Pharmacy and Pharmaceutical Sciences., vol. 2, 18 22, 2010.

[31] https://arxiv.org/ftp/arxiv/papers/1601/1601.04159.pdf, diakses pada 7/8/2021.

[32] H. Budiman. "Evaluasi dan Interpretasi Statistik Hasil Pengukuran Menggunakan Certified Reference Material”, Warta Kimia Analitik., vol. 20, Serpong: Pusat Penelitian Kimia LIPI, 2014.

[33] https://members.aoac.org/AOAC_Docs/StandardsDevelopment/SLV_Guidelines_Dietary_Supplements. pdf, diakses pada 17-09-2021.

[34] A. Kumar, L. Kishore, N. Kaur, and A. Nair. "Method development and validation: Skills and tricks", Chronicles of Young Scientists., vol. 3, no.1, pp. 3-11, 2012.

[35] S. Abdelghani-Idrissi, N. Dubouis, A. Grimaud, P. Stevens, G. Toussaint, and A. Colin. "Effect of Electrolyte Flow on A Gas Evolution Electrode". Scientific Reports., vol. 11, no. 1, pp. 1-15, 2021.

[36] N. Hamim, F. S. H. Krismastuti, A. Hindayani, and Y. Aristiawan. "Certified Reference Materials for Calibration of Conductivity Meter at The Measuring of Electrolytic Conductivity in Water: Preparation and Its Measurement", AIP Conference Proceedings., vol. 2175, 020065-1 - 020065-9, 2019.

[37] Research Center for Metrology - LIPI. (2017): Report of Proficiency Testing Program: Elctrolytic Conductivity (DHL17).

[38] Z. Moron and T. Grysiński. "How to Measure Electrolytic Conductivity Successfully", XXI IMEKO World Congress, Praha, Republik Ceko, 2015.

[39] https://www.tau.ac.il/ chemlaba/Files/Theoryconductivity.pdf, diakses pada 29/12/2021.

[40] F. Werne. "Sertifikat Uji Sel tipe E", ZMK\&ANALYTIK GmbH, Jerman, 2015.

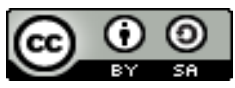

Jurnal IJCA is licensed under aÂ Creative Commons Attribution ShareAlike 4.0 